\title{
Magna Carta, canon law and pastoral care: excommunication and the church's publication of the charter
}

\section{Felicity G. Hill}

This article argues that the Church's strenuous efforts to publicise Magna Carta can only be fully understood when viewed in the context of canon law and pastoral care. In the late middle ages, the Church provided that Magna Carta be read out in parish churches throughout England on a frequent basis, in the vernacular, because of requirements that parishioners be given adequate religious instruction. The automatic sentence of excommunication that fell on anyone who infringed Magna Carta meant that every Christian in medieval England needed to know not just the general principles of the Charter, but the contents of every clause. Clergymen had a duty to ensure that their parishioners did not incur excommunication - which threatened salvationthrough ignorance. This excommunication thus had a profound effect on the political awareness of English society. Knowledge of Magna Carta's contents reached people at all levels of society as a result of the Church's obligation to look out for the spiritual welfare of its members.

In 1225, Magna Carta was redrafted, and the final version, which was to be repeatedly confirmed, came into force. Whatever the debate about the role of Stephen Langton, archbishop of Canterbury (1207-1213), in the drafting of the original 1215 charter, it is highly likely that he was instrumental in the creation of the definitive text issued in $1225 .{ }^{1}$ In addition, he pronounced a solemn sentence of excommunication against those who infringed Magna Carta and the Charter of the Forest. ${ }^{2}$ This occasion began a tradition in which the charters were confirmed and reissued in return for the granting of taxes to the king, and a tradition of ecclesiastical support for the charters demonstrated through sentences of excommunication against those violating their terms. Churchmen supported Magna Carta for a number of reasons. The charter's first clause defended ecclesiastical liberties, while the church also benefitted, as a great landholder, from the chapters

\footnotetext{
1 'Magna Carta, 1225': Appendix 12 in J. C. Holt, Magna Carta (2 ${ }^{\text {nd }}$ edn., Cambridge, 1992). D. A. Carpenter, 'Archbishop Langton and Magna Carta: His Contribution, His Doubts and His Hypocrisy', English Historical Review 126 (2011), 1041-65, and n. 1 for references to the debate about Langton's contribution in 1215.

${ }^{2}$ Councils and Synods II 1205-1313, ed. F. M. Powicke and C. R. Cheney (2 vols., Oxford, 1964) [hereafter Councils and Synods], p. 138, n. 1.
} 
regulating the running of local government and facilitating the expansion of the common law. ${ }^{3}$ Equally, many churchmen believed strongly in the general principle of subjecting the king to the law and thus saw Magna Carta's value as a symbol of limited monarchy. ${ }^{4}$

As a result, English prelates from Langton to Winchelsey (Archbishop of Canterbury, 1294-1313) played an important role in securing confirmations of the charter and in disseminating copies of it to the localities. ${ }^{5}$ Copies of the charter were sent to cathedrals and monasteries to be kept there, and were read out in public. ${ }^{6}$ A number of the copies still extant were probably the results of the church's efforts to promulgate the charter. ${ }^{7}$ As well as playing a key part in publicising Magna Carta, the church became the 'custodian of the charters' when c. 61, which in 1215 had sanctioned war on the king if he infringed the charter, was removed and excommunication was introduced as its only means of enforcement. ${ }^{8}$ While it is undeniable that many churchmen strongly supported the principles of Magna Carta, and that this support was an incentive to publicise it, this excommunication generated other reasons why Magna Carta had to be disseminated, that were not to do with politics, but rather related to canon law and pastoral care.

${ }^{3}$ Carpenter, 'Archbishop Langton and Magna Carta', 1056-7; D.A. Carpenter, Magna Carta (London, 2015), pp. $122-23$.

${ }^{4}$ D. L. d'Avray, “"Magna Carta”: Its Background in Stephen Langton’s Academic Biblical Exegesis and its Episcopal Reception', Studi Medievali, $3^{\text {rd }}$ ser. 38 (1997), 423-38.

${ }^{5}$ The Church was particularly instrumental in the confirmations in 1253 and 1270, for example. See 'D. A. Carpenter, 'Magna Carta 1253: the ambitions of the church and the divisions within the realm', and 'More light on Henry III's confirmation of Magna Carta in 1253', Historical Research 86 (2013), 179-95, and J. R. Maddicott, The Origins of the English Parliament, $924-1327$ (Oxford, 2010), p. 271. The Church was also significantly involved in the Confirmatio Cartarum, and had been resisting taxation longer than the laity: J. H. Denton, Robert Winchelsey and the Crown 1294-1313: A study in the defence of ecclesiastical liberty (Cambridge, 1980), p. 168.

${ }^{6}$ e.g. Confirmatio cartarum (1297), cc. 3\&4; Select Charters and Other Illustrations of English Constitutional History from the Earliest Times to the Reign of Edward the First, W. Stubbs, 9th edn. (Oxford, 1913), pp. 490-91. See also Carpenter, Magna Carta, pp. 430-5 on proclamations and copies of the charters.

${ }^{7}$ N. Vincent, Magna Carta: Making and Legacy (Oxford, 2015).

${ }^{8}$ J. W. Gray, 'The Church and Magna Charta in the century after Runnymede', Historical Studies: Papers Read Before the Irish Conference of Historians, VI (1968), pp. 23-38, p. 24. 
Although the excommunication pronounced by bishops on numerous occasions during the thirteenth century was a symbolic gesture, demonstrating the support of the church for what the charter represented, its importance beyond this has been doubted. J. W. Gray argued that 'its practical effect was negligible', and that it was 'nothing more than a pious gesture'. ${ }^{9}$ Its success in curbing the actions of kings was indeed limited, and, despite complaints of the clergy that the king was not adhering to the charters, occasions when the sentence was enforced against individuals are extremely few. ${ }^{10}$ Gray discussed in some depth the various problems with the enforcement of the sentence, and showed that it did little to restrain lay encroachments on ecclesiastical liberties (though it is impossible to tell to what extent it worked as a deterrent). Yet the sentence's impact was not negligible. Despite the practical limitations of the sentence, it was widely publicised. The publicity given to both the excommunication and Magna Carta was remarkable, and had important effects for the longevity of the sentence and the awareness of the charter at all levels of English society.

There is no doubt that publication of the excommunication and the charters could be political in nature. Efforts made to broadcast the charter and excommunication were inextricably linked to the struggles between the king and his subjects (both clerical and lay). Publication frequently followed confirmation. Prelates and baronage often worked together to obtain confirmations and reissues, but bishops could also be the 'driving force' in such negotiations, as was the case in $1253 .{ }^{11}$ Matthew Paris wrote that after this confirmation, Robert Grosseteste, bishop of Lincoln (1235-53), had the excommunication pronounced in every parish church of his

\footnotetext{
${ }^{9}$ Gray, pp. 27, 35.

${ }^{10}$ See Gray's discussion. Two individual cases may be found in Les Registres d'Alexandre IV (1254-1261), ed. C. Bourel de la Roncière et al, (3 vols., Paris, 1895-1959), ii, 2650, and in The Historians of the Church of York and its Archbishops, ed, James Raine, Rolls Series (3 vols., 1879-94), iii, pp. 183-84; the king was reminded of the sentence by Alexander IV: Matthew Paris, Chronica Majora, ed. H. R. Luard, Rolls Series (7 vols., 1872-83), vii

(Additamenta), pp. 332-4.

${ }^{11}$ Carpenter, 'Magna Carta 1253', 180.
} 
diocese, because he feared that the king would renege on his promises to keep to the charters. ${ }^{12}$ Paris thus explained the action as intended purely to restrain the king. But on other occasions, there was no immediate reason why the charters should be publicised.

In 1279, John Pecham, archbishop of Canterbury (1279-90), provoked the wrath of King Edward I with certain clauses of his provincial legislation issued at the Council of Reading. The clauses at issue involved general excommunications, and a command that Magna Carta, written clearly, should be displayed in all cathedral and collegiate churches, easily visible and replaced each year. The king forced Pecham to revoke these constitutions in parliament soon after, and although the archbishop again pronounced the excommunications in his council of Lambeth two years later, the order to display Magna Carta was not repeated. ${ }^{13}$ The Reading sentences led to the display of the charter for at most a few months. ${ }^{14}$ Nevertheless, the extreme reaction of the king has provoked comment on the prudence of the archbishop's order. Pecham's biographer, Decima Douie, judged it to have been 'tactless', and 'in the nature of a challenge', while R. M. Haines wrote that it was injudicious, perhaps even provocative. ${ }^{15}$

Despite Edward I's reaction, a lot more than politics was going on here, and the aim of this article is to put the order made at Reading, and the church's publication of Magna Carta and its sentence of excommunication more generally, into a different context. Pecham issued his order during an ecclesiastical council, and the clause should not be separated from the other matters at stake there. When the order is set in the context of canon law, the pastoral concerns

\footnotetext{
${ }^{12}$ Matthew Paris, Chronica Majora, v, p. 378; Councils and Synods, p. 476.

${ }^{13}$ Councils and Synods, pp. 851, 856-7. It is worth noting that the king also objected to the seventh Reading excommunication, which had first been issued by Langton in 1222, and numerous times thereafter. Pecham cannot be deemed provocative in this case, despite Edward I's reaction.

14 The phrasing of Pecham's declaration in parliament, that 'he would remove Magna Carta from the doors of churches' implies that the order to display it had indeed already been fulfilled.

${ }^{15}$ Decima L. Douie, Archbishop Pecham (Oxford, 1952), pp. 118-9; R. M. Haines, 'Conflict in Government: Archbishops versus Kings, 1279-1348' in Aspects of Late Medieval Government and Society: Essays Presented to J. R. Lander, ed. J. G. Rowe (London, 1986), p. 218.
} 
that obsessed much of the episcopate of England (and elsewhere) during the thirteenth century, and the efforts better to educate parish clergy as a result of these, it is possible to see that dissemination of the charter, from an ecclesiastical perspective, was not only desirable, but necessary. This was because excommunication was involved: souls were at stake.

The automatic sentence of excommunication - called a lata sententia - attached to the charter required publication. The original decision to cover the charter with excommunication should certainly be seen in a political context. Indeed, ideological concerns can be detected behind the majority of latae sententiae (mostly relating to the sanctity of the church, its members, and its possessions). Nevertheless, once the sentence was established - particularly once it had been confirmed by the papacy - canon law demanded that the excommunication and the charter be publicised, with important consequences for the history of Magna Carta.

Major excommunication was the church's most severe penalty, and meant separation from the whole communion of the faithful, both in life and in death. For this reason, the law increasingly emphasised and decreed that sentences of excommunication must be issued only with caution, following a proper procedure. Thus, c. 47 of the Fourth Lateran Council (1215), referring to $a b$ homine sentences (sentences imposed on an individual by a particular cleric, distinct from latae sententiae), declared how serious it would be to excommunicate unjustly, providing detailed provisions to prevent this, with penalties for those who issued unjust excommunications. Most important among the increased legal requirements for ecclesiastical censures was provision of adequate warning. Warnings had to be given, in the presence of witnesses, before any sentence was promulgated. ${ }^{16}$ The Council of Lyons (1245) ordered that excommunications had to be made in writing as well as pronounced orally, and that the reason for the sentence must be expressly written down, with a copy made available on request to any

\footnotetext{
${ }^{16}$ Decrees of the Ecumenical Councils, ed. and trans. Norman P. Tanner (2 vols., London, 1990), i, p. 255.
} 
person so sentenced. ${ }^{17}$ These requirements were for excommunications $a b$ homine. The nature of latae sententiae, however, meant that warnings could not possibly be given before a sentence took effect, because the excommunication was incurred automatically, as soon as the condemned act was committed, as the law stated. This type of sentence was thus also termed an ipso facto or de jure excommunication.

Excommunication lata sententia officially came into existence at the Second Lateran Council (1139), with the canon Si quis suadente (C. 17 q.4 c. 29$).{ }^{18}$ This pronounced anathema on anyone who assaulted a cleric or religious. Due to its automatic nature, which prevented the possibility of trial or warning, the sentence was a matter of prolonged controversy amongst canonists and decretalists. Notably 'Gratian', the compiler of the Decretum (c. 1140-50), did not fully accept it. It was therefore necessary to justify a sentence that was automatic in this way. The canonists made such sentences acceptable, or at least defensible, by stating that all crimes which incurred excommunication ipso facto must be made known to all, through regular reiteration. The canon lawyer, Huguccio, thus refuted objections that there was no warning for these sentences: frequent publication of latae sententiae acted in lieu of warning. ${ }^{19}$

Evidence that this requirement for frequent publication was implemented can readily be found in England. Stephen Langton's provincial Council of Oxford (1222) opened with the recital of seven ipso facto sentences, to be pronounced yearly in episcopal synods, and four times a year in parish churches. ${ }^{20}$ Thenceforth, these latae sententiae and certain others (additions or sentences of local importance) became prominent in diocesan and provincial legislation. Although lists of these sentences in diocesan, provincial, and legatine councils and synods

${ }^{17}$ Decrees of the Ecumenical Councils, i, p. 291-2.

${ }^{18}$ Corpus iuris canonici, ed. Friedburg (2 vols., Leipzig, 1881), i, col. 1575.

${ }^{19}$ For the development of this type of sentence see Huizing, Peter, 'The earliest development of excommunication latae sententiae by Gratian and the earliest decretists', Studia Gratiana 3 (1955), 277-320; E. Vodola, Excommunication in the Middle Ages (Berkeley, 1986), pp. 28-35; R.H. Helmholz, The Spirit of Classical Canon Law (London, 1996), pp. 383-90.

${ }^{20}$ Councils and Synods, pp. 106-7, 125. 
varied, their prominence is clear. ${ }^{21}$ They were supposed to be solemnly pronounced on a regular basis - the precise frequency varied a great deal in the instructions, from as often as every Sunday to only twice a year, with four times a year being the most common. Sometimes, it was specified that the full ritual of excommunication, with bells ringing and candles being held alight, then extinguished, was to accompany the reading of these sentences. ${ }^{22}$ This was almost certainly always the intention, although not always stipulated.

Not only were instructions that latae sententiae be pronounced frequently commonplace in English legislation, but there is some indication that they were seen as among the most important parts of it. Thus, in 1239, Robert Grosseteste issued statutes for the diocese of Lincoln, which he ended by expressing concern that, as he had heard, the decrees of the Council of Oxford (Langton's 1222 council) were not written in many churches. ${ }^{23}$ To remedy this, he added to his document not the entire constitutions of 1222, but a small selection of them, singling out the beginning of the council with its excommunications intended 'to terrify the wicked and restrain their wickedness'. Grosseteste ordered that these excommunications be renewed yearly in every church. The seven Oxford sentences follow. ${ }^{24}$ Forty years later at the council of Reading, John Pecham demonstrated the importance of latae sententiae when he ordered the yearly publication of his own constitutions, those of the legatine council in London (1268), as well as a list of ipso facto excommunications which he had gathered from four councils (to be published four times a year). ${ }^{25}$ Pecham acknowledged that the councils of Langton (1222), Otto (1237), Boniface of Savoy (1261) and Ottobuono (1268), were all of importance, but

\footnotetext{
${ }^{21}$ There are too many occasions when such orders were made to list. Cheney's index of Councils and Synods provides over 30 page references for 'Excommunication: in genere: publication periodically'. See also index entry for the 1222 Council of Oxford, which provides references for when its excommunications were quoted or ordered to be recited.

${ }^{22}$ For example, Councils and Synods, pp. 355-7, 625-6, 1057-9, 1192-6.

${ }^{23}$ Presumably 'non est scriptum Oxoniense concilium' meant that these churches did not possess copies.

${ }^{24}$ Councils and Synods, pp. 275-6.

${ }^{25}$ Councils and Synods, p. 851.
} 
Ottobuono's (with certain additions from Boniface's) sufficed, since so much of the earlier material was repeated. But he had specifically sought to gather together the excommunications from all four councils because they were of such importance. They were not simply repeated routinely, as much legislation was, but were important enough to be collected comprehensively. Such a comprehensive list ought to (and did) contain the Magna Carta excommunication, which by this time had existed for over half a century.

The Magna Carta excommunication, because it was an ipso facto sentence, required frequent pronunciation, just like any other lata sententia. Given the weight attached to publishing latae sententiae in ecclesiastical councils, it follows that similar provisions for publication accompanied the Magna Carta sentence. It did, however, differ from the other automatic sentences in two important ways. First, it was attached to documentary texts - the 1225 Magna Carta and Forest Charter. The other excommunications were never more than a few lines long. They might be open to interpretation, but the law itself was set out in a relatively concise clause. ${ }^{26}$ The Magna Carta sentence, by contrast, was simply a notification that every clause in the charter and the Charter of the Forest was covered by automatic excommunication. It made no sense without the charters: pronouncing the excommunication was pointless if nobody knew what the charters themselves contained. After the excommunication was confirmed by Pope Innocent IV in 1254, the dean of Lincoln, Richard Gravesend, was appointed to promulgate it throughout England. ${ }^{27}$ The letter by which he sought to enforce this mandate, which he sent to bishops or their officials the following year, quoted Innocent's letter (which itself quoted the excommunication at length), and went on to order that the excommunication be pronounced. ${ }^{28}$ This was to be done not only in churches, but also in various secular meeting places, in both

\footnotetext{
${ }^{26}$ The first clause of the Council of Oxford, which guaranteed the liberties of churches, was expounded later in the century, so that it was rather longer and more specific by 1281 than it had been in 1222. Cf. Councils and Synods, p. 106 with pp. 848-9 and pp. 905-6.

27 The dean of London was also appointed but excused himself.

${ }^{28}$ Annales Monastici, ed. H. R. Luard, Rolls Series, (5 vols., 1864-1869), i, pp. 320-22.
} 
English and French 'distinctly and plainly'. ${ }^{29}$ The Burton Annals, in which the letter survives, affirm that this was done throughout the country. Gravesend additionally sent a copy of the sentence, so that copies could be made and thus notice of it would reach everyone. Attempting to dispel ignorance, fearing lest anyone be bound by the sentence through it, he also sent out copies of the two charters. Again, copies were to be made (though he wanted his own copies returned to him). The context for the confirmation, and the publication, were certainly political, but what must be understood is that it was the excommunication that was being publicised, and the charter sent alongside it. Magna Carta was not being promulgated in its own right, but rather as a gloss on the sentence which covered it.

The second difference between the Magna Carta excommunication and other English latae sententiae lay in the circumstances in which it originated. The other sentences came from church councils and were thus immediately part of ecclesiastical law. By contrast, the Magna Carta sentence was not included in a list of excommunications along with the others in a provincial council until 1279 (though it was mentioned in Boniface's 1261 Council at Lambeth $^{30}$ ). The lapse of over fifty years before the Magna Carta excommunication was included in ecclesiastical legislation alongside other latae sententiae requires explanation. The answer probably resides in the fact that it had originally been created in rather different circumstances. The other latae sententiae can certainly be set in political context, and ecclesiastical councils often had political agendas, but they were part of promulgated constitutions. When the Magna Carta sentence was first pronounced in 1225, it was only that: pronounced. ${ }^{31}$ There is no evidence of a written text before 1253. It is possible that there were written texts on occasions before this, but it seems likely that on these occasions the sentence

\footnotetext{
${ }^{29}$ Substantially the same letter, sent to William of Kilkenny, bishop-elect of Ely, is in Cambridge, University Library MS. EDC 1/B/95.

${ }^{30}$ Councils and Synods, p. 672.

${ }^{31}$ The same may be said for other sentences pronounced between 1225 and 1253. A particularly significant sentence was pronounced in 1237: Councils and Synods, pp. 205-7.
} 
was proclaimed, solemnly and ritually in the presence of the king, and that this ritual was the principal means of publication. ${ }^{32}$ This was important for those present, but there was less emphasis on dissemination and promulgation. Other excommunications pronounced in this way, as for example a sentence pronounced in support of reforms made in 1259, were only of significance for a limited period of time. ${ }^{33}$ This might have been true of the Magna Carta sentence. But because the Charter remained in force, and because it continued to be used as a bargaining tool, the excommunication also remained active.

The turning point here was 1253. The excommunication, pronounced in Westminster Abbey on 13 May 1253, by Archbishop Boniface of Savoy and thirteen of his suffragan bishops, produced a written text, of which two versions circulated, one by the king, and one by the bishops. ${ }^{34}$ Though the former included fewer concessions to the church, it was the version circulated by the bishops that lasted, and that was disseminated. It was copied again and again, and became extremely well known. ${ }^{35}$ What the church was trying to achieve in 1253 is complicated, and has been discussed elsewhere, but part of the prelates' achievement lay in securing papal confirmation of the bishops' written sentence of excommunication. ${ }^{36}$ While this was important for other reasons, here it is significant because it gave the sentence the highest form of backing. Popes Innocent IV and Alexander IV both confirmed it, something often mentioned when the excommunication was cited by clergymen. ${ }^{37}$ This may perhaps explain why

\footnotetext{
${ }^{32}$ For the chronicle evidence of earlier sentences of excommunication pronounced, see Councils and Synods, pp. 138, n. 1 (1225) and 206-7 (1237).

${ }^{33}$ No written text survives, it is described most fully by Arnold fitz Thedmar: De Antiquis Legibus Liber: Cronica Maiorum et Vicecomitum Londoniarum, ed. T. Stapleton, (Camden Soc., xxxiv, 1846), p. 42.

${ }^{34}$ Councils and Synods, pp. 474-9.

${ }^{35}$ Besides innumerable copies in statute books, the 1253 excommunication can be found in a large number of other manuscripts, notably monastic cartularies. See English Episcopal Acta 35: Hereford 1234-1275, ed. Julia Barrow (Oxford, 2009), pp. 43-6.

${ }^{36}$ Carpenter, 'Magna Carta 1253', and Gray.

${ }^{37}$ Les Registres d'Innocent IV, ed. É. Berger (4 vols., Paris, 1884-1921), iii, 8070; Concilia Magnae Britanniae et Hiberniae, ed. David Wilkins (4 vols., London, 1737), i, p. 730; see also Councils and Synods, p. 474, n. 1.
} 
the sentence was not included in ecclesiastical legislation until the second half of the century; in the first few decades of its existence the Magna Carta excommunication had been a political ritual. It had mattered at the highest political level but had not, so far as we know, be 'routinised' in the life of the English church. A written text, and papal confirmations, changed this, and explain the delayed inclusion of this sentence amongst other ipso facto excommunications in English ecclesiastical law. Whatever the background to the decision to attach a ipso facto excommunication to Magna Carta, once this had been done, and repeated numerous times and confirmed by the papacy, the canonical obligation to make it known could not be ignored.

Nevertheless, it was not just obedience to the letter of the law that required the Magna Carta sentence to be made known to everyone in the English church. There was a far more serious reason to do so: major excommunication endangered one's soul. It was thus the duty of any cleric with a cure of souls to ensure that those entrusted to them were not so endangered through ignorance of automatic sentences. For bishops, this also meant that they needed to instruct their subordinates, particularly parish priests, so that they could care for their flocks. Publication of the Magna Carta excommunication, and the charter itself, must be viewed alongside the thirteenth-century emphasis on pastoral care, and on equipping parish clergy adequately to administer such care. Excommunication, as a spiritual sanction, was clearly an important part of the cura animarum. The emphasis on publication of ipso facto sentences in thirteenth-century England probably owed more to this than to canonical requirements.

The precise implications of excommunication for the soul were rather ambiguous. The ritual and words used in denunciations implied damnation. Yet theologians insisted it meant no such thing. The Council of Lyons (1245) emphasised that excommunication was 'medicine, not death, discipline not annihilation' (cum medicinalis sit excommunicatio non mortalis, disciplinans non eradicans). ${ }^{38}$ But elsewhere, rather the opposite sentiment was expressed. Thus

\footnotetext{
38 Tanner, Decrees of the Ecumenical Councils, i, p. 291.
} 
the second diocesan statutes of Exeter (1287), following a clause found in Gratian, stated that 'excommunication is damnation of eternal death' (cum excommunicatio eterne mortis sit dampnatio). ${ }^{39}$ The Council of Lambeth (1281), referring to the practice of priests absolving those who they were not entitled to absolve de jure, said that in so doing they 'bring back to life ... souls that do not live'. ${ }^{40}$ These souls had been plunged into a 'sea of damnation'. ${ }^{41}$ Whatever the disagreements about the precise results of excommunication, it was certainly treated as a serious matter. Lateran IV made clear that 'it is not a trivial fault to inflict so great a punishment on an innocent person' ${ }^{42}$ The consequence of this was that excommunications latae sententiae were at the forefront of the knowledge that clergy with cure of souls had to possess in order to protect their parishioners.

Excommunications incurred ipso facto were of course not the only concern of pastoral reformers in the thirteenth century. Other aspects of the Christian faith also needed to be publicised, particularly the articles of faith. In 1215, c. 21 of the Lateran Council, which famously required every Christian to confess their sins at least once a year, demanded frequent publication in churches, 'lest anyone obtain the veil of excuse from the blindness of ignorance'. ${ }^{43}$ Precisely this reasoning was used when discussing automatic excommunications in provincial and diocesan legislation. The context of this was often pastoral, and even when not explicitly so, the general mood of reform and the aims of these councils and synods was pastoral.

Excommunication was so important in this context because, as Leonard Boyle pointed out, it was the censure most likely to affect the laity, and so it was paramount that members of the ecclesiastical hierarchy were familiar with it. 'Ignorance, whether culpable or reasonable,

\footnotetext{
${ }^{39}$ Councils and Synods, p. 1040, and n. 3. cf. Decretum Gratiani C. 11 q. 3. c. 41: quia anathema est æternæ mortis damnatio: Corpus iuris canonici, i, col. 1239.

${ }^{40}$ i.e. absolutions reserved to bishops or the papacy.

41 'in dampnationis pelagum demerguntur', Councils and Synods, pp. 898-9. Pecham specifically cites the Oxford latae sententiae as being open to this danger.

42 Tanner, Decrees of the Ecumenical Councils, i, pp. 225-6.

${ }^{43}$ Tanner, Decrees of the Ecumenical Councils, i, p. 245.
} 
defeated the idea which lay at the root of the censure-system of the church. ${ }^{34}$ The fear that ignorance would provide an excuse was a recurrent theme. It was, for instance, used in 1255 in the promulgation of the papal confirmation of the Magna Carta excommunication: 'lest through ignorance the malediction binds anyone who is ignorant' ${ }^{45}$

The concern was that souls would be endangered through ignorance of ipso facto sentences, since it was the church's duty to prevent this. Thus parish priests needed to have copies, not only in order to pronounce the sentences frequently, but also so that they could explain them to the laity in the vernacular. ${ }^{46}$ Knowledge of them became an integral part of clerical education. ${ }^{47}$ This may have been why Grosseteste was so concerned that the excommunications remained unreported in writing in many churches, when he expressed his anxiety in 1239. The statutes of Wells (c. 1258) and Exeter (1287) both ended with lists of excommunications and provisions for their regular pronouncement in parish churches, ordering that every church have a copy of these present statutes. This was so that parish priests could read them over many times and learn them by heart (quasi cordetenus), so that they would be able more easily to explain them to the laity, in the vernacular. ${ }^{48}$ Orders that automatic excommunications either be pronounced or explained in the vernacular were frequent, particularly towards the end of the thirteenth century and beyond. In 1309, Robert Winchelsey ordered that certain statutes and 'cases in which a sentence of major excommunication is imposed ipso facto by sacred canons, should be publicly published with the multitude of the

\footnotetext{
44 'A study of the works attributed to William of Pagula, with special reference to the Oculus sacerdotis and Summa summarum' (Oxford University D.Phil. thesis, 1956), p. 297.

45 'Ne autem aliquos ignorantes maledictum per ignorantiam involvat',.Annales Monastici, i, p. 322.

46 That priests read from lists is indicated by an assault made on a priest while he was pronouncing the Oxford excommunications in 1293, when the list from which he was reading them was snatched from him: The Rolls and Register of Bishop Oliver Sutton, 1280-1299, ed. R. M. T. Hill (8 vols., Lincoln Record Society, 1948-75), iv, p. 35.

${ }^{47}$ For education of the clergy in this period in general, see R. M. Haines, 'Education in English ecclesiastical legislation', Studies in Church History 7: Councils and Assemblies, ed. G. J. Cuming and Derek Baker (Cambridge, 1971), pp. 161-75.

${ }^{48}$ Councils and Synods, pp. 625-6, $1057-9$ ('in vulgari').
} 
faithful present [four times a year] lest the pretext of ignorance of such excommunications and statutes can excuse them ... [and] they should be published distinctly and intelligibly in the vernacular'. He threatened punishment against anyone who was negligent in carrying out his orders. ${ }^{49}$ Similarly, in 1269 Godfrey Giffard, bishop of Worcester (1268-1301), ordered the Magna Carta excommunication to be promulgated in all collegiate and parish churches. It was to be plainly expounded to both the literate and the unlettered, in the vernacular. ${ }^{50}$

The pastoral importance of publishing latae sententiae can be seen in Pecham's instructions at his second provincial council at Lambeth. The archbishop included a significant clause, known as the Ignorantia sacerdotum, supplying a syllabus of what priests needed to know to care for their charges. It included the articles of faith, the sacraments, the seven deadly sins and seven principle virtues, the Ten Commandments, and other vital Christian knowledge. This famous constitution was a pastoral aid, establishing those things that the clergy were expected to explain to the laity four times a year, vulgariter, and had a considerable impact on subsequent pastoral literature. ${ }^{51}$ It is less well known that it was paired with the following clause, containing ipso facto sentences, which was to be published at the same time. ${ }^{52}$ Archdeacons were to ensure that publication of the two clauses, on moral instruction and on excommunications, was not 'rashly omitted' by negligent priests. ${ }^{53}$ The two clauses were thus part of the same effort to reform pastoral care. Between them, the crucial aspects of religion for lay society were covered.

\footnotetext{
${ }^{49}$ Councils and Synods, p. $1275-7$ ('distincte et intelligibiliter in vulgari').

${ }^{50}$ Wilkins, Concilia, ii, pp. 22-3 ('tam literatis quam illiteratis exponi dilucide in vulgari'). Further orders for vernacular publication of the Magna Carta, the charter's excommunication, and other ipso facto sentences can be found in Councils and Synods, pp. 1089 ('lingua materna ... distincte et aperte') and 1192-6 ('in vulgari'; 'in anglico seriatim in omnibus ac patenter'; 'ut hoc ad notitiam singulorum perveniat, in anglico exponatur'); Annales Monastici, i. 321 ('distincte et dilucide, in lingua Anglicana et Gallicana').

${ }^{51}$ Councils and Synods, pp. 900-5; see Douie, Archbishop Pecham, pp. 134-42; R. M. Haines, Ecclesia Anglicana:
} Studies in the English Church of the Later Middle Ages (Toronto, 1989), pp. 133-7, and his notes.

52 'Eisdem etiam temporibus sententie publicentur', Councils and Synods, pp. 905-7.

${ }^{53}$ Councils and Synods, p. 907. 
There is no doubt that the pastoral concerns of the bishops were genuine and intense. Langton, Grosseteste, Pecham, Winchelsey, to name a few, were all deeply involved in politics, but saw that salvation of souls was their most important duty. In 1239, Grosseteste wrote about the dangers of giving cure of souls to those unwilling, unable, or untrained to discharge the responsibilities that this bestowed. In his letter (one of many examples) he refused to institute an illiterate man, for to do so would be for the bishop himself to 'drown in the depths of the sea'. Christ had suffered on the cross in order to save souls, and for those not tending to their sheep, 'how great will be their suffering in hell when they ... neglect salvation of souls' ${ }^{54}$ He could not in good conscience allow an unfit man into such a position. The bishop's diatribes against absentee clergy and those holding multiple benefices stemmed from his concern that this would lead to loss of souls. As those who have focussed on Grossesteste's life and writings have observed, the cure of souls was his most pressing concern, and affected all his actions. ${ }^{55}$ As John Pecham wrote almost fifty years later, 'nothing is more precious on earth than the cure of souls, since Christ offered himself on the cross for this alone'. ${ }^{56}$

Excommunication therefore became an important feature of the pastoral literature that proliferated in the wake of the Fourth Lateran Council, as well as the legislation already discussed. Lists of absolutions reserved to the papacy or bishops were a notable genre, as were lists of latae sententiae. ${ }^{57}$ Local priests needed to know both. As early as c. 1216, Thomas of Chobham discussed latae sententiae, and noted that different regions enforced different ipso

\footnotetext{
${ }^{54}$ The Letters of Robert Grosseteste, Bishop of Lincoln, ed. F. A. C. Mantello and Joseph Goering (London, 2010), pp. 229-30.

${ }^{55}$ W. A. Pantin 'Grosseteste's Relations with the Papacy and the Crown', in Robert Grosseteste: Scholar and Bishop, ed. D. A. Callus (Oxford, 1955), p. 179; J. R. Ginther, 'Robert Grosseteste's Theology of Pastoral Care', in A Companion to Pastoral Care in the Late Middle Ages (1200-1500), ed. Ronald J. Stansbury (Leiden, 2010), p. 978.

${ }^{56}$ Councils and Synods, p. 1078.

${ }^{57}$ For reserved absolutions see J. Longère, 'Les évêques et l'administration du sacrement de pénitence aux XIIIe siècle: les cas réservés', in Papauté, Monachisme et Théories Politiques II: Etudes d'histoire medieval offertes à Marcel Pacaut, ed. P. Guichard et al. (2 vols., Lyon, 1994), ii, pp. 537-50.
} 
facto excommunications. Therefore, every priest needed to know the synodal constitutions of his bishopric, so that he would know by which deeds his parishioners were excommunicated by the law itself, and which not. ${ }^{58}$ Later manuals, such as Grosseteste's Templum Dei, sought to provide such lists. ${ }^{59}$ One of the particularly significant characteristics of the Oculus Sacerdotis, compiled c. 1320, was that it included a comprehensive list of both papal and English automatic excommunications. William of Pagula, the compiler, recognised that excommunication was a crucial aspect of cure of souls, and dedicated a large section to the censure, especially on reserved absolutions and excommunications incurred ipso facto. Indeed the ipso facto sentences were deemed so important by Pagula that he included a second list (in a different section of his manual), which only included those of more frequent occurrence (thirty-four rather the somewhat unmanageable ninety of the earlier list). ${ }^{60}$ The last in both these lists was the excommunication attached to Magna Carta and the Forest Charter. In the longer list, the two charters themselves were included, along with the full text of the 1253 sentence. $^{61}$

The purpose of the lists in both legislation and priests' manuals was to ensure that the best possible pastoral care could be provided, by ensuring that clergy with a cure of souls were familiar with whatever might endanger their parishioners' salvation. The same desire lay behind

${ }^{58}$ Thomae de Chobham Summa Confessorum, ed. F. Bloomfield (Louvain, 1968), pp. 250-1.

${ }^{59}$ Robert Grosseteste, Templum Dei, edited from MS. 27 of Emmanuel College, Cambridge by Joseph Goering and F.A.C. Mantello (Toronto, 1984), p. 40; L. E. Boyle, 'The Oculus Sacerdotis and some other works of William of Pagula', Transactions of the Royal Historical Society, $5^{\text {th }}$ ser., 5 (1955), [Repr. Boyle, Pastoral Care, Clerical Education and Canon Law, 1200-1400 (London, 1981)], 88, n.1, and Boyle, 'A study in the works', p. 300.

${ }^{60}$ There are 90 separate excommunications. Boyle mentions 140 because each separate clause (of which there are fifty) of Magna Carta and the Forest Charter was covered by excommunication. Boyle, 'The Oculus Sacerdotis', 8790; British Library, Royal MS. 8 C II, fos. 67ra-73rb, the shorter list is at fos. 85vb-87ra. Here the English excommunications precede the papal. The texts of the charters are not included in the shorter list, but the reader is informed that they contain 50 articles, and is directed to find them in c. 20 of the Speculum prelatorum (another of Pagula's works).

${ }^{61}$ The importance of this was noted by W.A. Pantin, who wrote that 'It is interesting to see how every parishioner was kept, or supposed to be kept, conscious of Magna Carta; it is clearly a mistake to imagine that the latter was something discovered by seventeenth-century politicians and lawyers.' The English Church in the Fourteenth Century (Cambridge, 1955), p. 198. 
the practice of frequent solemn pronunciation. When Oliver Sutton, bishop of Lincoln (1280-99), published the ipso facto sentence attached to the papal bull Clericis laicos, in the midst of what was very definitely a political struggle between king and church, in $1297,{ }^{62}$ he explained why it was his duty to do so:

Prelates who are appointed to the custody of their flock ... cannot dissimulate nor be silent from reprehension and exhortation: If, when I say to the wicked, you shall surely die, and you give him no warning, nor speak to warn the wicked from his wicked way, in order to save his life, then that wicked person shall die for his iniquity, but his blood I will require at your hand. But if you warn the wicked, and he does not turn from his wickedness, or from his wicked way, then he shall die for his iniquity, but you will have delivered your soul. (Ezechiel 3:18-19). Because ... [certain people] have incurred such sentences of excommunication, mindful prelates have need of denouncing such sentences, to make them more openly manifest, so that he who feels himself to have incurred one has cause of seeking remedy for himself and to abstain from such occurrences thereafter. ${ }^{63}$

The point Sutton was making, expanding on c. 7 of the Fourth Lateran Council and citing the Bible, was that he was responsible for his flock, and it was he who would have to answer to God if he did not do everything in his power to protect those under his care. When Pecham introduced his list of excommunications at Reading, he too linked their publication with his pastoral duty:

Because it is not possible to avoid evil unless it is known, but there are many sentences of excommunications, by which wicked men are struck down ... we order all the priests of the province of Canterbury openly to set forth the sentences of excommunication which follow, to the people entrusted to them, on all Sundays immediately following the celebration of the rural chapter, lest henceforth through ignorance they are plunged into the pit of such great danger. ${ }^{64}$

\footnotetext{
${ }^{62}$ For the reception of Clericis laicos in England see Denton, pp. 80-99.

${ }^{63}$ The Rolls and Register of Bishop Oliver Sutton, vi, pp. 24-5.

${ }^{64}$ Councils and Synods, p. 848
} 
As the archbishop phrased it, evil is impossible to avoid unless it is known. The sentences were automatic, so in order to be avoided they needed to be known, otherwise his flock would be plunged into the 'pit' (foveam) that was excommunication. The Statutes of Exeter II (1287) also introduced the list with an explicit reference to its pastoral purpose: 'so that we look out for the salvation of our subordinates more cautiously, lest they incur sentences of excommunications brought ipso facto through ignorance in any way, we have decided to insert the sentences of excommunications [...] ${ }^{65}$ Both the Reading and the Exeter lists - placed firmly in the context of pastoral care - ended, of course, with the excommunication attached to Magna Carta.

The most striking demonstration of how crucial publication of these sentences had become is found, however, in the writings of Walter Bronescombe, bishop of Exeter (1258-80), not in statutes, but in a mandate specifically dedicated to the publication of articles of excommunication. The letter, sent in $1277^{66}$ (and thus before Pecham's council of Reading) articulates the absolute necessity of having this done, as well as providing a possible precedent for Pecham's order that Magna Carta be placed somewhere where all entering church could see it.

Among the other anxieties of pastoral care which rest upon us, the reason for the coming of our Redeemer, Who came not only for the sake of the just but for all who had died, unceasingly arouses the duty of our office and diligently summons us to watch over the safety of souls, wholesomely to preserve in health the sheep of the flock entrusted to us, and by the remedy of salvation to lead back those to the path of truth who have strayed in error so that they may be cured, lest - which God forbid - they perish through our dissimulation and we be punished by God's judgement for our negligence on their account. Indeed, certain of our parishioners through a certain very great ignorance of letters do not know the statutes of the canons and the traditions of the holy fathers, and have frequently fallen under sentences of excommunication ... which we relate with sorrow, and unwisely believe that they may do what is unlawful; in order that the snare of

\footnotetext{
${ }^{65}$ Councils and Synods, p. 1057.

${ }^{66}$ The letter is undated, but comes in the register after letters dated Jan., Feb. and March 1277. It is referred to in a letter dated 14 Aug. 1277.
} 
such sentences may be with circumspection avoided and the blindness of ignorance shut out, we command you ... that you should have the articles set out below, on account of which sentence of excommunication is incurred ipso facto, published by parish priests in every collegiate and parish church on every Sunday. ... You are to enjoin on every rector, vicar and parish priest of such churches that each of them should, within a month, have the contents of the present letter clearly posted up in a prominent place in their churches, under threat of a penalty to be assessed at the judgement of the ordinary. ${ }^{67}$

Although Bronescombe referred to general 'ignorance of the statutes', this introduction was followed by only twelve ipso facto sentences. The fifth of these, following the 1253 sentence, excommunicated 'all those who by any art or device violate, diminish or alter ... the customs of the realm, and especially the liberties and free customs contained in the charters of common liberties and of the forest $\ldots$ in any article whatever' ${ }^{68}$ He referred to the same letter some months later and, again ordering publication, he referred to Gregory the Great, 'for there is no excusing the shepherd if the wolf eats the sheep without the shepherd's knowledge'. ${ }^{69}$

Just as Grosseteste had feared that, should he institute an inappropriate man to a cure of souls, he would have to answer to the 'dreaded Judge' and himself drown in the depths of the sea, Bronescombe knew that to be negligent would incur the punishment of God. If people fell into such sentences, the bishops, as their shepherds, would be culpable for not providing the necessary information. If people still fell into them knowingly, they themselves would be damned, but the bishops would have performed their duties and at least saved their own souls. In practice, those who incurred these sentences through ignorance were given some leeway, but it

\footnotetext{
${ }^{67}$ The Register of Walter Bronescombe, Bishop of Exeter 1258-1280, ed. O. F. Robinson (3 vols., Canterbury and York Soc. 1995-2003), no. 1222.

${ }^{68}$ The $6^{\text {th }}$ excommunication in Bronescombe's list also came from the 1253 sentence of excommunication, forbidding anyone to introduce or obey statutes or customs made against the liberty of the church (cf. X 5.39.49) ${ }^{69}$ Register of Walter Bronescombe, no. 1229; Gregory the Great, Registrum Epistolarum Libri I-VII, ed. D. Norberg, Corpus Christianorum Series Latina 140 (Turnhout, 1982), liber III, ep. 52; The phrase was incorporated into the Liber extra, X 5.41.10: Corpus iuris canonici, ii, col. 1965.
} 
was thus still necessary for priests to know so that they could be warned and swiftly make satisfaction for their wrongs. ${ }^{70}$

This was why Magna Carta had to be published. There was a serious omission from Bronescombe's mandate: telling everyone of the dire consequences of infringing the charter 'in any article whatever' was both pointless and irresponsible if nobody knew what these articles contained. It should come as no surprise, then, that Pecham should have noticed this omission and sought to rectify it two years later. Pecham may not have known of Bronescombe's order (though the bishop was almost certainly present at Reading to inform him ${ }^{71}$ ). Despite this, there is a striking correlation between Bronescombe's order about his list of latae sententiae, which were to be affixed in a prominent place in collegiate and parish churches, and Pecham's order for Magna Carta. They are most easily compared in the Latin.

singuli eorum presencium tenorem in suis singulis collegiatis et parochialibus ... in suis ecclesiis ... in loco eminenti patenter affixum. ${ }^{72}$

bene et aperte conscriptam infra singulas ecclesias cathedrales seu collegiatas in loco puplico iubemus affigi, ut omnium intrantium oculis se palam exhibeat et in fine anni in vigilia Paschatis perpetuo renovetur, ut sublata veteri nova recensque bene scripta substituatur eidem. ${ }^{73}$

\footnotetext{
${ }^{70}$ Two weeks was given for those who had incurred a sentence unknowingly in which to make satisfaction for the crime committed. If they did not, they would then be bound by the sentence. See the terms of the 1253 Magna Carta excommunication, and Register of Walter Bronescombe, no. 1229. For a lata sententia to be legally enforced, an individual or publica fama would need to alert the church that someone had incurred the sentence. The bishop or his official would then order an investigation to be carried out, which would be followed by court proceedings. An excommunication ab homine in court would ensue if the person was found guilty and refused to make satisfaction or to appear, thereby acting contumaciously. A record of such a sentence would be necessary to stop an excommunicate prosecuting in court, for instance, which was forbidden. Absolution from the lata sententia would have to be sought directly from the pope or archbishop if the excommunication was reserved, as latae sententiae often were, unless a dispensation was granted. I plan to discuss how latae sententiae worked in practice more fully elsewhere.

${ }^{71}$ Councils and Synods, p. 829.

${ }^{72}$ Register of Walter Bronescombe, iii, no. 1222.

${ }^{73}$ Councils and Synods, p. 851.
} 
This order ended the council of Reading, and should be seen alongside the other agenda there. Pecham's list of excommunications (c. 11) was immediately followed by a clause warning bishops about ipso facto sentences that they were in danger of incurring themselves (c. 12). The next clause (c. 13), fearing lest ignorance provided any excuse, ordered the recital and publication of the legatine council of 1268, and the excommunications incurred ipso facto which Pecham had extracted from four councils, to be published in both minor and major churches four times a year. The next and final clause of the council (c. 14), which ordered that the council's own constitutions be impressed upon everyone twice a year, and that Magna Carta should be posted up in churches and replaced yearly, should not be separated from the other canons of the council. In the context of publication of ecclesiastical statutes, and especially those things which were most needed by parish clergy to exercise their duty of cura animarum, Magna Carta needed to be made known.

The wording of Pecham's order has long been a matter for discussion. ${ }^{74}$ The archbishop emphasised that the charter should be legible: well and clearly written and replaced yearly so that it remained so. Yet surely most people would be unable to read such a text? It was also supposed to be easily visible to anyone entering these churches. John Maddicott has argued that Pecham's order 'showed the almost totemic value attached to the charter and its seeming role as a visual icon, to be observed rather than read (Pecham said nothing about reading it)' ${ }^{75}$ If this were the case, it makes the need for legibility rather odd. Though by no means certain, it is possible to suggest a solution to the puzzle. If the order is seen in the context of clerical education, it makes more sense. The intention may have been that priests would have free and easy access to the text,

\footnotetext{
${ }^{74}$ Hilda Jonstone, 'Archbishop Pecham and the Council of Lambeth 1281', in Essays in Medieval History Presented to Thomas Frederick Tout, ed. A. G. Little and F. M. Powicke (Manchester, 1925), p. 174, n. 3.

75 'Politics and People in Thirteenth-Century England', in Thirteenth Century England XIV: Proceedings of the Aberystwyth and Lampeter Conference 2011, ed. Janet Burton, Phillipp Schofield and Björn Weiler (Woodbridge, 2013), p. 9.
} 
so that they could read and learn it, perhaps even make copies. It would of course also have been deemed beneficial for unlettered laity to see the document and to bear in mind the serious consequences of infringing it, but it had to be easily readable so that it could be read and understood. It was crucial that clergymen could do this, so that they could explain to others, making it desirable, but less critical, that everyone in the country should know the full text.

Nicholas Vincent has observed that 'it was the spirit, rather than the letter' of Magna Carta that enjoyed the greater fame. ${ }^{76}$ But the church had to ensure that the specifics, not just the spirit, were understood. In a pastoral context, Magna Carta as a symbolic document was irrelevant. A vague idea that it was about limiting monarchy, and had a clause about lawful judgement by one's peers, was completely insufficient. It was necessary to know that c. 23 said that fish-weirs were forbidden in the Thames and the Medway, and so on through each and every clause. Therefore, when William of Pagula included Magna Carta in his list of excommunications incurred ipso facto, he used an abbreviated text. ${ }^{77}$ What was important was the content of each clause, and each was of equal value in terms of protecting souls. Priests needed to know them all. Like many of the bishops from the thirteenth century, Pagula supported the principles in Magna Carta. He wrote a letter to Edward III complaining that the liberties guaranteed in it were disregarded, and he included the substance of the two charters and of the excommunication in all three of his works. ${ }^{78}$ These churchmen supported the charters because of

\footnotetext{
${ }^{76}$ Nicholas Vincent, The Magna Carta, Sotheby's, New York, December 18, 2007, p. 20. The 'Magna Carta Project', however, has shown that there was also intense interest in the details, and that the charter was repeatedly copied, and differences between versions noted. See Carpenter, Magna Carta, pp. 430-5.

${ }^{77}$ Brit. Libr., Royal MS. 8 C II, fos. 71ra-73rb. In the form: 'Statuitur quod' for each clause. The Forest Charter was included in full, presumably because the text was much shorter. I have no explanation for why Pecham did not order that the Forest Charter should be displayed in public. It is possible, and certainly not inconceivable, that he took for granted that the two automatically went together.

${ }^{78}$ Specifically, Pagula told the king that his ministers were 'members of the devil' as a result of incurring the excommunication: William of Pagula, The Mirror of King Edward III, trans. Cary J. Nederman, Political Thought in Early Fourteenth-Century England (Turnhout, 2002), pp. 63-139, p. 78; Boyle, 'The Oculus Sacerdotis', p. 423, and n. 31 .
} 
the liberties the charters upheld, on behalf of both church and people. This support was part of the reason why the charters continued to be of relevance, since they were cited and called for repeatedly. But the charters' context in the Oculus sacerdotis was pastoral not political. If David d'Avray has written that Magna Carta's inclusion in a priests' manual is a 'striking fact', it need not be interpreted as being the result of the charter being a symbol of limited monarchy. ${ }^{79}$ Even if the clergy had disagreed with the principles in the charters, they had a duty to make them known. To omit this would be negligent, and they would have to answer to God for any souls lost as a result.

This cura animarum imperative to include Magna Carta in pastoral manuals contributed significantly to the manuscript transmission of the charter in the late middle ages. Pagula's Oculus Sacerdotis survives in some fifty manuscripts; there are thirteen extant copies of his Summa summarum (and more survive in fragments); while the Pupilla oculi (1385), a manual derived from the Oculus, survives in forty copies, and was printed several times in the fifteenth and sixteenth centuries. ${ }^{80}$ All three manuals contain Magna Carta, the Charter of the Forest, and the 1253 sentence of excommunication. The Summa summarum contains the full text of Magna Carta, whereas the other two use an abbreviated text (all three include the Forest Charter and sentence of excommunication in full). ${ }^{81}$ Furthermore, the laity might have come into contact with the charters through confession. Pagula expected priests to warn bailiffs not to host 'scotales',

\footnotetext{
${ }^{79}$ d'Avray, p. 433-4. It is in fact equally striking that the 1253 Magna Carta excommunication, essentially a liturgical document - invoking the authority of the Trinity and numerous other religious authorities in order to excommunicate, anathematize and sequester wrongdoers from the threshold of the Holy Church - was included in numerous secular statutes books, presumably used by lawyers and the like; Councils and Synods, p. 475.

${ }^{80}$ Boyle, 'The Oculus Sacerdotis', 94-5; L. E. Boyle, The "Summa summarum" and some other English works of Canon Law', Proceedings of the Second International Congress of Medieval Canon Law, ed. Stephan Kuttner and J. Joseph Ryan (1965), 415-456, [Repr. Boyle, Pastoral Care], appendix III; Joseph Goering, 'Burgh, John (fl. 13701398)', Oxford Dictionary of National Biography (Oxford, 2004); John de Burgh, Pupilla oculi (London, 1510). For the importance and influence of these and other fourteenth-century manuals see Pantin, Chapter 9.

${ }^{81}$ Oculus sacerdotis: Brit. Libr., Royal MS. 8 C II, fos. 71ra-73rb; Summa summarum: bk 5, c. 61 (Brit. Libr. Royal MS. 10 D X was used by the author); Pupilla oculi: part V, c. 22.
} 
for example, because if they did they were ipso facto excommunicated because they had violated the Charter of the Forest. ${ }^{82}$ In the Pupilla oculi, priests were told to ask specific questions to penitents: a merchant should thus be told that if he use false measures, in violation of Magna Carta c. 22 , he was excommunicated. ${ }^{83}$

The Church's efforts to publicise the charters and their excommunications should certainly be seen as a parallel to secular proclamations and postings of political material. Similar public and vernacular announcements were also made in the secular sphere. It should be recognised, however, that the church had an added, religious, reason for reading out the charters. As a result of the excommunication attached to them, the charters were sent out to the localities, perhaps posted in public, proclaimed and expounded in the vernacular, and included in manuals written for parish priests which were used into the sixteenth century ${ }^{84}$ Canonical and pastoral concerns thus had a significant effect on the history of the charters, and on political awareness amongst the English population. These actions caused a great proportion of peasants and those lower in society to learn what the Charters of Liberties contained. In addition, the ritual that accompanied the denunciations made what was being said more memorable. As Archbishop Winchelsey put it in 1298, in an order to publish sentences of excommunication (including the Magna Carta sentence), laypeople paid more attention to the solemnity of such sentences,

\footnotetext{
82 'Item monere debet quod nullus forestarius vel bedellus faciat scotallas vel colligat garbas vel aliquam faciat collectam quod si fecerit est ipso facto excommunicatus quia facit contra cartam de foresta, cum omnes facientes contra carta de foresta sunt ipso facto excommunicati, ut patet ( $m s$. uxor) in carta de foresta et in sentencia lata', Brit. Libr. Royal MS. 8 C II, f. 84ra.

${ }^{83}$ John de Burgh, Pupilla oculi, part V, c. 9 ('de interrogationibus [in confessionibus] in speciali faciendis, et de differentiis personarum'), para. D.

${ }^{84}$ The Pupilla oculi was compiled in 1385 and later printed several times. Pecham's list of ipso facto sentences was included by William Lyndwood in his Provinciale (c. 1434), Book V, tit. 7. The gloss directs the reader to the Pupilla for the text of Magna Carta. W. Lyndwood, Provinciale (Oxford, 1679), p. 354. The Provinciale was printed many times between 1483 and 1679, including in English translation. R. H. Helmholz, 'Lyndwood, William (c.1375-1446)', Oxford Dictionary of National Biography (Oxford, 2004).
} 
intended to scare them, than to the actual consequences of incurring excommunication. ${ }^{85}$ Excommunication was a particularly good means of disseminating information. Political concerns were undoubtedly a motive for these efforts, but these pastoral fears must also be taken into account. The automatic excommunication attached to each clause of Magna Carta caused the charter to become not just a political tool but a commonplace, a part of parish life, by the end of the thirteenth century. Frequent denunciation in the vernacular in the presence of the English people from all levels of society, of both sexes, was ordered by bishops who were acutely aware of their pastoral duty to inform the people of anything which could impede their salvation. Magna Carta fell into this category; pastoral care necessitated that every English Christian know its contents, in every clause.

${ }^{85}$ Councils and Synods, pp. 1194-5. 